\title{
PENERAPAN STRATEGI MULTIPLE GAMES UNTUK MENINGKATKAN KEMAMPUAN MEMBACA PERMULAAN SISWA KELAS I SD NEGERI PENANGGUNGAN MALANG
}

\author{
Sri Agustin Mulyani \\ e-mail: mulyanisriagustin@yahoo.com
}

\begin{abstract}
Ability to read the beginning of first grade students is still low. This is due to classroom teachers SDN Indemnity Malang I have not utilize strategies that can foster students' interest in learning. Under these conditions, the necessary research that can improve beginning reading skills through the implementation of strategies Multiple Games. This study used a qualitative approach to the design of action research. Implementation results show that this strategy can improve reading skills beginning with an average percentage continues to increase from cycle I to cycle III.
\end{abstract}

\begin{abstract}
Abstrak: Kemampuan membaca permulaan siswa kelas I masih rendah. Hal ini disebabkan guru kelas I SDN Penanggungan Malang belum memanfaatkan strategi yang dapat menumbuhkan minat siswa dalam belajar. Berdasarkan kondisi tersebut, diperlukan penelitian yang dapat meningkatkan kemampuan membaca permulaan melalui penerapan strategi Multiple Games. Penelitian ini menggunakan pendekatan kualitatif dengan rancangan penelitian tindakan. Hasil penerapan menunjukkan bahwa strategi ini dapat meningkatkan kemampuan membaca permulaan dengan rata-rata persentase yang terus meningkat dari siklus I sampai dengan siklus III.
\end{abstract}

Kata Kunci: membaca permulaan, strategi multiple games

Menurut Syafi'ie (1992:2) kemampuan dan keterampilan baca tulis, khususnya keterampilan membaca harus dikuasai oleh para siswa di SD karena kemampuan dan keterampilan ini secara langsung berkaitan dengan seluruh proses belajar siswa di SD. Keberhasilan belajar mereka dalam mengikuti proses belajar mengajar di sekolah ditentukan oleh penguasaan kemampuan membaca mereka. Siswa yang tidak mampu membaca dengan baik akan mengalami kesulitan dalam mengikuti kegiatan pembelajaran untuk semua mata pelajaran. Mereka akan mengalami kesulitan dalam menangkap dan memahami informasi yang disajikan dalam berbagai buku pelajaran, bukubuku bacaan penunjang, dan sumber-sumber tertulis yang lain, siswa tersebut akan lamban sekali dalam menyerap pelajaran. Akibatnya kemajuan belajarnya juga lam- ban jika dibandingkan dengan teman-temannya yang tidak mengalami kesulitan dalam membaca.

Tujuan membaca permulaan di kelas I adalah siswa dapat membaca kata-kata dan kalimat sederhana dengan lancar dan tepat (Depdiknas: 2003). Dipihak lain Syafi'ie (1999: 15), mengemukakan tujuan membaca permulaan adalah untuk menguasai suatu sistem tulisan sebagai representasi visual bahasa (learning to read) berupa ketepatan dalam mengucapkan dan melagukan lambang-lambang bahasa tulis. Ketertarikan mengangkat membaca untuk penelitian ini karena kemampuan membaca permulaan sangat berpengaruh terhadap keberhasilan membaca lanjut dan membaca pemahaman, yang berimplikasi pada keberhasilan mempelajari berbagai mata pelajaran di Sekolah Dasar. 
Salah satu alternatif yang diduga dapat mengatasi masalah pembelajaran membaca permulaan tersebut adalah menggunakan strategi Multiple Games. Dalam permainan ini menggunakan berbagai kartukartu yang digunakan sebagai alat permainan dan ditempelkan pada papan flanel. Strategi Multiple Games merupakan kolaborasi berbagai permainan yaitu, permainan identifikasi kartu gambar, kartu huruf, kartu kata, dan kartu suku kata.

Banyak faktor yang menjadi penyebab belum maksimalnya kemampuan membaca siswa. Dalam hal ini yang menjadi faktor utama adalah kurangnya kreativitas dan kemauan dari guru untuk mencoba menggunakan media pembelajaran yang bervariasi. Hal tersebut juga didukung oleh sejumlah penelitian. Penelitian yang dilakukan oleh Enny Zubaidah (1988) yang berjudul Diagnosis dan Tindakan Perbaikan Kesalahan Membaca Kelas I di SDN Penanggungan 3 Malang ditemukan siswa kelas I SD masih melakukan 14 jenis kesalahan membaca. Hasil penelitian tersebut menunjukkan bahwa kemampuan membaca siswa kelas I SD masih belum sesuai yang diharapkan. Penelitian yang dilakukan Siti Nisrina 2000) berjudul Pembelajaran Membaca Permulaan Melalui Permainan Bahasa ditemukan bahwa masih banyak siswa kelas rendah yang belum dapat membaca dengan lancar.

Berdasarkan studi pendahuluan yang dilakukan di kelas I SD Negeri Penanggungan Malang. Tercatat kondisi sebagai berikut, (1) guru belum memanfaatkan media pembelajaran yang variatif, (2) guru belum kreatif dalam menyusun alat bantu belajar siswa, (3) guru belum memodifikasi bahan, pendekatan dan strategi pembelajaran yang dapat menumbuhkan minat siswa dalam belajar, (4) siswa kurang diberi aktivitas personal dan kelompok yang mengakibatkan kebosanan siswa dalam belajar, (5) guru lebih mementingkan penilaian hasil daripada proses, (6) siswa kurang termotivasi un- tuk aktif, senang dan berpikir kritis dalam pembelajaran (7) pembelajaran membaca belum pernah dilaksanakan melalui permainan, dan (8) hasil pembelajaran membaca permulaan hanya mencapai $61.16 \%$. Sehubungan dengan kenyataan di atas maka dikembangkan suatu strategi pembelajaran yang dapat digunakan sebagai alternatif meeningkatkan kemampuan membaca permullaan, yaitu strategi Multiple Games penelitian ini bertujuan mendeskripsikan proses dan hasil penerapan strategi Multiple Games dalam meningkatkan kemampuan membaca permulaan. Penelitian ini diharapkan berguna bagi sekolah, guru dan peneliti lanjutan. Dengan penelitian ini diharapkan guru dapat memanfaatkan hasil penelitian ini sebagai alternatif stategi dalam pembelajaran membaca permulaan dan juga merupakan sumbangan pikiran untuk meningkatkan keberhasilan membaca permulaan di kelas I dengan menggunakan strategi Multiple Games sebagai media pembelajaran. Bagi peneliti lanjutan hasil ini dapat memperkaya wawasan, pengetahuan dan refernsi tentang penggunaan strategi Multiple Games dalam pembelajaran.

\section{Metode}

Untuk mencapai tujuan penelitian di atas, digunakan pendekatan kualitatif dalam bentuk Penelitian Tindakan Kelas (PTK). Menurut Zuriah (2002:16) esensi penelitian tindakan terletak pada adanya tindakan dalam situasi yang alami untuk memecahkan permasalahan-permasalahan praktis atau meningkatkan kualitas praktek.

Sumber data penelitian ini berasal dari proses pelaksanaan pembelajaran membaca permulaan dengan strategi Multiple $\mathrm{Ga}$ mes yang meliputi tahap awal, tahap penyusunan, dan tahap akhir, penilaian dan perila$\mathrm{ku}$ guru dalam pembelajaran. Adapun teknik pengumpulan data dilakukan dengan observasi, wawancara, tes, dan catatan lapangan. 
Analisis data dilakukan selama penepenelitian ini berlangsung dan didasarkan atas langkah-langkah menurut Miles dan Huberman (1992:18), yaitu reduksi data, penyajian data, dan penyimpulan data. Penelitian ini dilaksanakan dengan tiga siklus, gambaran kriteria keberhasilan dilihat dari perbandingan antara nilai sebelum pemberian tindakan dan sesudah pemberian tindakan. Kriteria keberhasilan penelitian ini adalah jika efektifitas penggunaan strategi Multiple Games dalam pembelajaran membaca permulaan baik kualifikasi proses dan hasil menunjukkan peningkatan hasil belajar siswa berkategori minimal baik (memiliki taraf keberhasilan 70\% sampai 84\%).

\section{Proses Penerapan Strategi Multiple Games dalam Pembelajaran Membaca Permulaan}

Proses penerapan strategi Multiple Games dalam pembelajaran membaca permulaan dilaksanakan dalam 3 siklus. Prosedur tindakan dilaksanakan sesuai dengan skenario pembelajaran, yaitu tahap awal, tahap penyusunan, dan tahap akhir. Langkahlangkah setiap tindakan tersebut dijelaskan sebagai berikut.

\section{1) Tahap awal}

Berikut beberapa hal yang dilakukan oleh siswa dan guru sebelum memulai permainan dengan strategi Multiple Games (a) Membuka skemata siswa tentang pembelajaran yang akan dilaksanakan, (b) mempersiapkan dan menentukan jenis kartu pemicu yang akan digunakan dalam pembelajaran membaca permulaan, yaitu kartu gambar, kartu huruf, kartu kata, dan suku kata, (c) mengelompokkan kartu-kartu sesuai dengan jenis permainannya dan (d) mempersiapkan kartu-kartu yang akan digunakan dalam permainan.

\section{2) Tahap Penyusunan}

Pada tahap ini siswa akan melakukan 3 aktivitas permainan, yaitu (a) permainan identifikasi gambar, (b) permainan kartu kata pemicu, dan (c) permainan raja. Sebelum permainan dimulai, guru menentukan dan membagi dalam kelompok sesuai kemampuan siswa. Pelaksanaan permainan tersebut sebagai berikut.

\section{a) Permainan Identifikasi Gambar}

Pada tahap ini siswa melakukan beberapa aktivitas berikut, (1) menjawab dengan tepat gambar yang ditempelkan pada papan flanel, (2) membaca gambar dan beberapa kalimat yang ada di bawah gambar, (3) meyusun kalimat sesuai gambar, (4) menguraikan kalimat menjadi kata, (5) menguraikan kata menjadi suku kata dan huruf, dan (6) menyusun huruf menjadi kalimat.

\section{b) Permainan Kartu Kata Pemicu}

Pada tahap ini siswa melakukan beberapa aktivitas berikut, (1) memperhatikan kalimat yang disebar acak, (2) mencari kartu kata sesuai kalimat acak yang disusun guru, (3) menyusun kalimat acak menjadi kalimat yang betul, dan (4) membaca kalimat dengan suara nyaring.

\section{c) Permainan Raja}

Pada tahap ini siswa melakukan beberapa aktivitas berikut, (1) mengambil salah satu huruf dan menyebutkan huruf yang ada di kartu sambil mengatakan aku raja ... (misalnya, aku raja A), (2) memperhatikan gambar yang ditempelkan guru, (3) menyusun huruf dan suku kata, dan (4) menyusun kalimat sesuai gambar.

\section{3) Tahap Akhir}

Pada tahap ini guru memberikan kesempatan kepada siswa untuk (1) memberikan kesan dan pengalaman sesudah melakukan permainan, dan (2) membaca teks secara individu.

Pelaksanaan pembelajaran membaca permulaan dengan strategi Multiple Games 
pada siklus I dilaksanakan dalam dua kali pertemuan dengan alokasi waktu $2 \times 30$ menit. Materi pembelajaran untuk pertemuan pertama adalah nama-nama binatang yang mempunyai suku akhir terbuka, sedangkan materi pada pertemuan kedua adalah namanama binatang dengan suku akhir tertutup.

Pada siklus II pelaksanaan pembelajaran membaca permukaan dengan strategi Multiple Games dilaksanakan dalam dua kali pertemuan dengan alokasi waktu 3 x 30 menit. Materi pelajaran untuk pertemuan pertama adalah nama-nama binatang yang mempunyai akhiran ng, sedangkan pada pertemuan kedua adalah nama-nama binatang dengan akhiran rangkap "au dan ai ". Selanjutnya pada siklus III pelaksanaan pembelajaran membaca permulaan dengan strategi Multiple Games hanya dilaksanakan pada satu kali pertemuan dengan alokasi waktu 3x30 menit. Materi pelajaran pada siklus ini adalah nama-nama binatang yang merupakan kata ulang.

Pelaksanaan pembelajaran membaca permulaan dengan strategi Multiple Games dilakukan dengan tiga tahap, yaitu tahap awal, tahap penyusunan, dan tahap akhir. Tahap awal merupakan tahap persiapan sebelum permainan dimulai. Tahap penyusunan adalah tahap pelaksanaan aktivitas permainan. Tahap akhir merupakan akhir dari pelaksanaan proses pembelajaran. Pembahasan tiap-tiap tahap tersebut dijabarkan sebagai berikut, pada tahap awal ditemukan bahwa (1) guru membuka skemata siswa tentang pembelajaran yang akan dilaksanakan, (2) menjelaskan langkah-langkah permainan yang akan dilaksanakan, dan (3) mempersiapkan jenis kartu yang akan dipergunakan dalam permainan, yaitu kartu gambar, kartu huruf, kartu suku kata, dan kartu kata. Guru memberikan kesempatan kepada siswa untuk belajar membaca dengan melakukan permainan kartu-kartu tersebut sehingga pembelajaran menjadi menyenangkan. Hal ini sesuai dengan pendapat Sadiman (dalam Mistiana, 2005) ya- ng mengemukakan, bahwa penggunaan media dapat menimbulkan kegairahan belajar, memungkinkan interaksi yang lebih langlangsung antara anak didik dengan lingkungan dan kenyataan, dan memungkinkan anak didik belajar sendiri-sendiri menurut kemampuan dan minatnya.

Menurut Syafi'ie (1999:19) pengehuan dan pengalaman tentang benda-benda, ide-ide yang dimiliki seseorang itu tersimpan dalam skemata. Tahap pembangkitan skemata adalah upaya melibatkan mental maupun fisik pada pengetahuan tentang topik yang akan dipelajari. Pembangkit skemata siswa terhadap efek yang dipelajari adalah usaha menggali pengetahuan dan pengalaman yang berkaitan dengan isi topik yang dipelajari Pada kegiatan membuka skemata siswa tentang materi yang akan didiajarkan, guru mengutamakan pertanyaan kepada siswa sebagai pancingan agar perhatian siswa terpusat kepada pembelajaran. Sebagaimana yang dikatakan Riyanto (200:117) bahwa bertanya dalam pembelajaran dipandang sebagai kegiatan guru untuk mendorong, membimbing, dan menilai kemampuan berpikir siswa. Bagi siswa bertanya merupakan kegiatan penting dalam melaksanakan kegiatan pembelajaran.

Pembangkit skemata yang dilakukan guru dalam pembelajaran tahap awal pada siklus I, II, dan III terungkap saat guru membuka pelajaran dengan memperlihatkan gambar pada siswa dan menjelaskan cara melakukan permainan dengan media kartu pemicu yang dipergunakan dalam permainan. Pada saat guru memperlihatkan kartu-kartu dan papan flanel, semua siswa antusias dan menunjukkan rasa ingin tahu yang besar. Tahap awal yang merupakan pembangkit skemata ini perlu dilakukan. Hal ini dibutuhkan untuk menjembatani kesenjangan antara apa yang diketahui siswa dengan apa yang akan dipelajari siswa. Hal ini juga sesuai dengan pendapat Burn dkk. (1996:209) yang menyatakan bahwa pembangkit skemata yang ditawarkan dapat me- 
nyebabkan terjadinya proses penghubung antara informasi tekstual dan pengetahuan atau pengalaman yang telah dimiliki siswa.

Pada tahap penyusunan, ditemukan bahwa aktivitas yang dilakukan guru adalah membagi siswa dalam kelompok-kelompok. Pada tahap ini siswa dibagi dalam 6 kelompok yang masing-masing beranggotakan 5 siswa. Pembagian kelompok ini sudah tepat, hal ini sesuai dengan pendapat Feldeman dan Arnold (dalam Mistianah: 2005) yang mengemukakan bahwa kelompok merupakan suatu kumpulan dua orang atau lebih yang berinteraksi satu sama lain, merasa saling berbagi kepentingan dan satu tujuan serta datang bersama-sama bekerja bersama untuk mencapai kegiatan kerja.

Pembagian kelompok pada tahap ini dilakukan secara heterogen dari segi kemampuan siswa dalam membaca, yaitu kategori rendah, sedang, dan tinggi. Hal ini dilakukan dengan pertimbangan jika semua anggota kelompok berkemampuan tinggi atau sedang dikhawatirkan akan terjadi kompetisi, sebaliknya jika semua anggota berkemampuan rendah maka aktivitas akan terhenti. Namun jika siswa mempunyai kemampuan berbeda dimasukkan dalam kelompok akan memberikan keuntungan bagi siswa yang berkemampuan rendah dan sedang. Sebaliknya siswa berkemampuan tinggi akan meningkat kemampuannya dalam berkomunikasi. Kelompok yang dibentuk dengan mempertimbangkan keanekaragaman kemampuan siswa akan menghasilkan kelompok belajar yang produktif.

Pada pelaksanaan pembelajaran membaca permulaan siklus I, II, dan III pembentukan kelompok sudah berdasarkan kemampuan siswa. Pada siklus II dan III guru memberikan identitas anggota dan membentuk ketua kelompok, hal ini dilakukan agar siswa lebih mudah mengenali kelomppoknya. Pembagian kelompok tersebut telah dapat meningkatkan kondisi belajar siswa yang efektif. Pada saat menyelesaikan permainan, anggota kelompok yang mampu membantu temannya yang mengalami kesulitan.

Kegiatan kedua pada tahap penyusunan dilanjutkan dengan melaksanakan aktivitas permainan. Pada siklus I, II, dan III siswa melakukan tiga permainan yaitu (1) permainan identifikasi gambar, (2) permainan kartu kata pemicu, dan (3) permainan raja. Pada tahap ini, hampir semua siswa mempunyai keberanian dan minat untuk melakukan permainan. Timbulnya keberanian dan minat siswa tersebut merupakan salah satu bukti kesiapan siswa untuk belajar. Hal ini sesuai dengan pendapat Syafi'ie (1999:10) yang menyatakan bahwa pada dasarnya kesiapan membaca terjadi bila mereka telah menguasai seperangkat kemampuan yang memungkinkannya untuk belajar membaca, antara lain kemampuan membedakan bunyi-bunyi yang didengar, mengetahui bahwa tulisan itu bukan gambar dan mengetahui bahwa huruf itu ada hubungannya dengan bunyi. Penggunaan media berupa kartu gambar, kartu huruf, kartu suku kata, dan kartu kata dapat mengairahkan siswa dalam belajar. Hal ini sesuai dengan pendapat Sudjana (1988) bahwa penggunaan media pembelajaran dapat meletakkan dasar-dasar yang nyata untuk berfikir yang mengurangi verbalisme, memperbesar minat dan perhatian siswa untuk belajar, memenumbuhkan kegiatan berusaha sendiri, membantu berkembangnya kemampuan berbahasa dan sebagai suatu strategi alternatif untuk meningkatkan keunggulan dalam belajar. Penggunaan media pada dasarnya dimaksudkan untuk merangsang minat dan upaya belajar siswa. Minat yang besar disertai upaya belajar sendiri akan meningkatkan perolehan belajar. Oleh karena itu dalam pembelajaran digunakan media yang sesuai dengan tujuan dan tingkat pengakuan siswa. Dengan demikian akan terjadi interaksi siswa dengan media dalam pembelajaran.

Selanjutnya, kegiatan ketiga yang dilakukan guru pada tahap penyusunan adalah 
memberikan latihan membaca pada siswa secara klasikal, kelompok dan individu. Latihan membaca tersebut meliputi aspek (1) membaca gambar, (2) membaca huruf, (3) membaca suku kata, (4) membaca kata, dan (5) membaca kalimat.

Latihan membaca gambar berfungsi mengenalkan pada siswa bentuk kongkret dari kata yang dibaca. Tampubolon (1999: 199-123) mengungkapkan bahwa siswa usia 6-7 tahun memerlukan gambar untuk membantu proses berpikirnya. Gambar dapat membantu siswa meningkatkan minat, motivasi, dan daya nalar sesuai dengan perkembangan jiwanya. Latihan membaca gambar yang dilakukan guru bertujuan agar siswa dapat mengenal kata yang ada di bawah gambar sebagai langkah awal dalam membaca huruf, suku kata, dan kata. Hal ini sesuai dengan pendapat Burn dkk. (1990) bahwa guru dapat menggunakan kartu-kartu bergambar sebagai media dalam menemukan permainan menemukan kata. Kartu-kartu gambar tersebut juga dapat dipergunakan oleh guru untuk mengenalkan benda-benda yang ada di sekeliling siswa. Guru memperlihatkan gambar dan siswa diminta membaca kata di bawah gambar. Guru juga dapat membacakan beberapa kalimat yang ada di bawah gambar.

Latihan membaca huruf dilakukan guru untuk mengingat huruf-huruf yang sudah diajarkan. Huruf adalah unsur terkecil dalam suatu bahasa, huruf juga dinamakan gambar bunyi suatu bahasa. Menurut Karwapi (1974:3) bahwa dalam waktu tertentu anak-anak diharapkan menguasai teknik membaca sambil mengenal semua tanda bunyi secara bertahap. Yang menjadi tujuan utama membaca permulaan ialah memperkenalkan kesatuan huruf-huruf kepada anak -anak, sehingga anak dapat mengucapkan setiap huruf tersendiri. Pada latihan membaca huruf, siswa mengambil kartu kata dan menyusun kartu kata pada papan flanel menjadi kalimat. Siswa menguraikan kali- mat tersebut menjadi kata, suku kata, dan huruf.

Pada latihan membaca suku kata kegiatan yang dilakukan siswa adalah menguraikan kata menjadi suku kata yang disusun pada papan flanel. Sesudah siswa dapat membaca kalimat, siswa dapat memulai menganalisis kalimat itu menjadi kata, suku kata, dan huruf (Zuhdi, 1997:57).

Latihan membaca kata diberikan guru dengan cara mengajak siswa menganalisis kalimat, hal lain yang dilakukan adalah menyusun kartu kata acak yang berupa kalimat yang susunannya salah menjadi kartukartu kata dengan kalimat yang benar. Sesuai dengan pendapat Karwapi (1974) ketika anak dapat mengucapkan setiap huruf tersendiri maka anak akan mendistribusikannya dalam wujud kata dan kalimat, serta paham makna yang terkandung dalam kata dan kalimat itu. Dengan menyusun kartukartu kata yang disusun acak menjadi kartukartu kata yang susunannya benar berarti siswa sudah paham akan makna yang terkandung dalam kata tersebut. Pada permainan raja, ditemukan latihan membaca kata, yaitu ketika siswa dapat menyebutkan huruf yang diambil dan mengidentifikasikan huruf tersebut dengan gambar. Siswa menyusun kartu kata menjadi kalimat sesuai dengan gambar.

Latihan membaca kalimat diberikan guru dengan cara mengajak siswa mebaca gambar dan menempatkan beberapa kalimat di bawah gambar. Untuk memudahkan pelaksanaan dalam membaca dapat digunakan kartu gambar, kartu huruf, kartu kata, dan papan flanel. Kartu-kartu dan papan flanel untuk menguraikan dan menggabungkan kembali akan lebih mudah. Setelah siswa dapat membaca kalimat di bawah gambar, siswa dapat menganalisis kalimat tersebut menjadi kata, suku kata dan huruf. Pada waktu latihan membaca kalimat, guru juga membetulkan cara membaca siswa dalam hal ketepatan menyuarakan tulisan, lafal dan intonasi dalam membaca sehingga 
kemampuan membaca siswa menjadi baik dan benar.

Pada tahap akhir ditemukan (1) kegiatan pelaksanaan membaca permulaan telah berjalan dengan baik sesuai dengan perencanaan yang telah ditentukan, dan (2) penjelasan langkah-langkah permainan sangat membantu siswa dalam memahami permainan yang dilakukan dan tugas membaca yang akan dikerjakan baik secara kelompok maupun secara individu.

Aktivitas yang dilaksanakan guru pada tahap akhir adalah memberikan kesempatan pada siswa untuk mengungkapkan kesan pembelajaran atau merefleksikan pembelajaran dengan menanyakan pada siswa tentang perasaan senang ketika belajar membaca sambil bermain. Seperti yang dikemukakan Riyanto (2005:119) bahwa pada akhir pembelajaran guru menyisakan waktu sejenak agar siswa melakukan refleksi berupa pernyataan langsung tentang apa yang diperolehnya dan kesan atau saran siswa mengenai pembelajaran hari itu. Guru juga memberikan pujian terhadap semua siswa yang sudah berperan dalam melakukan pujian tersebut merupakan wujud pemberian motivasi agar siswa mempunyai rasa percaya diri dan keberanian dalam belajar. Pujian adalah bentuk reinforcement yang positif dan sekaligus motivasi yang baik. Pujian yang datangnya dari luar kadang-kadang diperlukan dan cukup efektif untuk merangsang minat (Russyan, 1992). Guru juga memberikan motivasi agar siswa mempunyai inisiatif merapikan kembali alat-alat permainan yang telah dipergunakan. Pada siklus I guru masih memberikan arahan dan bimbingan dalam merapikan, tetapi pada siklus berikutnya siswa sudah dengan tertib merapikan kembali alat-alat permainan yang dipergunakan.Guru juga mengingatkan siswa untuk mengulang kembali pelajaran di rumah. Hal ini tepat dilakukan karena siswa kelas I SD masih memerlukan bimbingan dan perhatian yang intensif dari orang tua.

\section{Hasil Penerapan Strategi Multiple Games dalam Pembelajaran Membaca Permulaan}

Pada tahap ini ditemukan beberapa hal, yaitu hasil tahap awal, tahap penyusunan, dan tahap akhir. Pada hasil tahap awal pelaksanaannya untuk mengetahui respon siswa terhadap pembelajaran membaca permulaan dengan strategi Multiple Games. Respon siswa sangat antusias, sebab strategi ini sangat menyenangkan dalam pembelajaran. Hal ini dibuktikan dengan keaktifan siswa saat melakukan permainan dan saat membaca kartu gambar, kartu huruf, kartu suku kata dan kartu kata. Wawancara yang dilakukan guru untuk mengetahui antusias siswa terhadap membaca permulaan dengan strategi Multiple Games meliputi siswa dengan kategori tinggi, sedang dan rendah. Hal ini dilakukan untuk mewakili siswa secara keseluruhan.

Dalam tahap ini juga ditemukan bahwa evaluasi yang dilaksanakan ada dua yaitu evaluasi proses dan evaluasi hasil. Evaluasi proses dilaksanakan pada saat permainan berlangsung, sedangkan evaluasi hasil dilaksanakan setelah akhir siklus pembelajaran. Sesuai dengan pendapat Akhadiah (1992:108) penilaian sebaiknya dilakukan ketika proses belajar mengajar sedang berlangsung dan setelah proses belajar mengajar selesai, yaitu penilaian proses dan peniian hasil.

Penilaian proses dilakukan untuk melihat bagaimana siswa memahami sesuatu konsep yang diberikan guru melalui proses belajar, sedangkan penilaian hasil lebih dilihat setelah suatu program selesai diberikan, kemudian siswa diberi tes atau penilaian.

Pada evaluasi tersebut ditemukan bahwa evaluasi proses dilakukan pada tahap penyusunan, sedangkan evaluasi hasil dilakukan pada tahap akhir. Evaluasi proses dilakukan dengan cara mengamati siswa selama kegiatan pembelajaran berlangsung dan evaluasi hasil dilakukan dengan memberi- 
kan tes membaca secara individu. Hal ini dilaksanakan untuk mengetahui hasil tujuan pembelajaran yang direncanakan. Sebagaimana dikatakan oleh Dimyati dalam Misdar (2006) bahwa untuk mengetahui tingkat keberhasilan siswa dalam mencapai tujuan yang ditetapkan maka diadakan evaluasi, di mana tingkat keberhasilan tersebut ditandai dengan skala nilai huruf, kata atau simbol Artinya evaluasi yang dilaksanakan tersebut dapat dituangkan dalam bentuk huruf atau angka pada hasil kerja siswa.

Pada tahap penyusunan penilaian didilaksanakan untuk melihat keefektifan strategi Multiple Games yang disesuaikan dengan materi yang tepat dan dilaksanakan secara kelompok. Penilaian ini juga berfungsi untuk mendiagnosis dan pengembangan pembelajaran. Artinya, kelemahan dan keunggulan siswa tersebut dapat ditemukan untuk merefleksi pembelajaran yang dilaksanakan, jika hasil belajar siswa baik berarti strategi yang digunakan memungkinkan untuk dikembangkan.

Pada tahap akhir, evaluasi dilaksanakan dengan waktu 30 menit. Hal ini sesuai pendapat Dimyati dalam Misdar (2006), bahwa waktu yang efektif digunakan untuk melaksanakan evaluasi terakhir 20 sampai 60 menit. Pada tahap ini guru memberikan tes membaca secara individu dengan menggunakan lembar tes sesuai dengan materi yang disampaikan dalam permainan. Lembar tes sebagai alat evaluasi disusun berdasarkan tujuan pembelajaran yang ingin dicapai yaitu, agar siswa dapat membaca kalimat sederhana dengan lafal dan intonasi yang wajar. Dalam pelaksanaan membaca permulaan tidak ada pedoman yang jelas mengenai bagaimana lafal serta intonasi yang tepat. Oleh karena itu yang dipakai sebagai pedoman ialah kewajaran: wajar, tidak dibuat-buat dan tidak terlalu menunjukkan ciri kedaerahan. Melalui pembelajaran membaca, siswa diharapkan mampu menyuarakan tulisan dengan lafal dan intonasi yang wajar (Zuhdi, 1997:122).
Dari uraian tersebut dapat dilihat bahwa butir-butir yang perlu diperhatikan dalam evaluasi pembelajaran membaca di kelas I adalah (1) ketepatan menyuarakan tulisan (2) kewajaran lafal, (3) kewajaran intonasi, (4) kelancaran, dan (5) kejelasan suara. Untuk menjaring data tentang butir-butir tersebut siswa diberi tugas membaca nyaring (bersuara) secara individu.

Penerapan strategi Multiple Games dalam pembelajaran membaca permulaan dari setiap siklus ditemukan ada peningkatan. Artinya dengan adanya refleksi yang dilakukan guru akan berdampak terhadap perbaikan pembelajaran, seperti penggunaan alat peraga pada siklus I ukuran kartunya kurang besar sehingga menyulitkan siswa dalam membaca. Pada siklus II dan III guru sudah menggunakan alat peraga dengan ukuran besar sehingga siswa termotivasi dalam belajar membaca. Pada siklus II dan III siswa sudah memahami permainan sehingga kesiapan mental siswa terhadap pembelajaran membaca permulaan dengan strategi Multiple Games semakin matang.

Berdasarkan evaluasi yang dilaksanakan pada tahap penyusunan setiap siklus, dari 3 siklus yang dilaksanakan ditemukan ada peningkatan setiap siklusnya. Pada siklus I tingkat keberhasilan pembelajaran yang dicapai pada aspek siswa 66.6\%. Pembelajaran pada siklus I dianggap tidak berhasil. Hal ini disebabkan karena siswa belum memahami dan terbiasa menggunakan per mainan dalam belajar membaca.

Hasil belajar tahap penyusunan pada siklus II dari aspek siswa rata-rata $80 \%$. Pembelajaran pada siklus II sudah berhasil, namun simpulan yang diambil masih se mentara. Guru masih perlu melakukan tindakan pembelajaran siklus III.

Pada siklus III tingkat keberhasilan pembelajaran yang dicapai pada aspek siswa rata-rata $93.3 \%$. Pembelajaran pada siklus III telah berhasil dan simpulan yang didapat sudah merupakan simpulan akhir. Jadi tidak perlu dilakukan siklus lanjutan. 
Berdasarkan evaluasi hasil yang dilaksanakan pada tahap akhir setiap siklusnya ditemukan adanya peningkatan. Evaluasi yang dilaksanakan pada tahap akhir ini dilaksanakan secara individu. Tugas yang diberikan guru pada evaluasi ini adalah (1) membaca gambar, (2) membaca huruf, (3) membaca suku kata, (4) membaca kata, dan (5) membaca kalimat.

Hasil belajar berdasarkan tes membaca yang dilakukan secara individu pada siklus I menunjukkan skor 2070 dengan ratarata 69 yang berkualifikasi $\mathrm{C}$ (cukup). Pada siklus II diperoleh skor 2464 dengan ratarata 82.13 berkualifikasi B (baik). Sedangkan pada siklus III hasil tes membaca mencapai skor 2614 dengan rata-rata 87.13 dengan kualifikasi A (sangat baik).

Hasil di atas menunjukkan bahwa kemampuan siswa pada siklus III mengalami peningkatan. Data tersebut membuktikan bahwa strategi Multiple Games dalam membaca permulaan semakin baik dan efektif dilaksanakan, dibanding dengan hasil membaca siswa sebelum tindakan yaitu $61.16 \%$.

Berdasarkan hasil tes membaca pada siklus III di atas semua siswa sudah mencapai target yang diharapkan yaitu $75 \%$. Ditemukan ada satu siswa yang belum memenuhi target, hal ini disebabkan siswa tersebut tergolong siswa berkebutuhan khusus yang memerlukan bimbingan intensif secara individual. Dengan demikian penelitian ini sudah berhasil dilaksanakan di SD Negeri Penanggungan I Malang.

\section{Simpulan}

Penerapan strategi Multiple Games untuk meningkatkan kemampuan membaca permulaan pada siswa kelas I SD Negeri Penanggungan Malang meliputi tahap awal, tahap penyusunan, dan tahap akhir. Tahap awal ditandai dengan aktivitas yang dilakukan guru yakni: (1) guru membuka skemata siswa dengan pertanyaan yang berkaitan de- ngan materi pelajaran untuk mengurangi kesulitan siswa dalam pembelajaran, dan (2) guru menjelaskan langkah-langkah yang ditempuh dalam pembelajaran agar siswa memiliki skemata terhadap pembelajaran tersebut. Tahap penyusunan ditandai dengan aktivitas guru yakni: (1) guru memberi penjelasan dan mendemonstrasikan kegiatan permainan dengan menggunakan alat peraga kartu-kartu pemicu dan dan papan flannel, (2) guru memberi tugas pada kelompok untuk melakukan tiga permainan, yaitu permainan identifikasi gambar, permainan kartu kata pemicu dan permaianan raja, dan (3) guru memberi tugas kelompok berlatih membaca dengan cara menyusun kartu-kartu tersebut sesuai perintah dalam permainan. Tahap akhir ditandai dengan aktivitas guru (1) memberikan kesempatan pada siswa untuk mengungkapkan kesannya selama pembelajaran, (2) memotivasi siswa untuk merapikan kembali alat-alat permainan yang sudah dipergunakan, (3) member tugas pada siswa untuk mengulang pelajaran di rumah, dan (4) memberi tugas pada siswa untuk membaca secara individu.

Hasil penerapan strategi Multiple Games yang meliputi tahap awal dapat meningkatkan respon siswa terhadap membaca permulaan yang meningkat secara positif: siklus I cukup positif, siklus II positif, dan siklus III sangat positif.

Hasil penerapan strategi Multiple Games pada tahap penyusunan dapat meningkatkan hasil membaca permulaan yang ditandai dengan kemampuan siswa dalam menyusun kartu gambar, kartu huruf, kartu suku kata dan kartu kata sesuai perintah dalam permainan serta dapat membaca kartukartu tersebut berkembang dengan baik. Proses penerapan strategi Multiple Games dalam pembelajaran membaca permulaan dari aktivitas siswa meningkat dari siklus I $66.6 \%$ dengan kualifikasi cukup, siklus II $80 \%$ dengan kualifikasi baik, dan siklus III $93.3 \%$ dengan kualifikasi sangat baik. 
Hasil penerapan strategi Multiple Games pada tahap akhir dapat meningkatkan kemampuan membaca permulaan yang ditandai dengan kemampuan siswa dalam hal membaca gambar, huruf, suku kata, kata dan kalimat yang berkembang, siklus I 69. 9\% dengan kualifikasi cukup, siklus II 82. $13 \%$ dengan kualifikasi baik, dan siklus III $87.13 \%$ dengan kualifikasi sangat baik.

Berdasarkan paparan data dan hasil pembahasan, maka dapat disimpulkan bahwa pelaksanaan srategi Multiple Games dapat meningkatkan kemampuan membaca permulaan siswa kelas I SD Negeri Penanggungan Malang.

\section{Saran}

Berdasarkan temuan tentang penerapan strategi Multiple Games dalam meningkatkan kemampuan membaca permulaan siswa diberikan saran kepada guru kelas I sebagai berikut (1) dalam membuat perencanaan pembelajaran membaca permulaan sebaiknya menggunakan strategi yang bervariasi dengan menggunakan berbagai permainan, salah satunya adalah dengan menggunakan strategi Multiple Games, (2) pada penerapan pembelajaran membaca permulaan sebaiknya dilaksanakan dengan cara membaca tanpa buku lebih dahulu, yaitu dengan pengunaan kartu gambar, kartu huruf, kartu suku kata dan kartu kata. Dengan menggunakan gambar dan kartu-kartu tersebut siswa dapat belajar sambil bermain, yaitu dapat menghubungkan antara gambar dengan kata ataupun dengan kalimat bermakna, serta siswa dapat membacanya dengan baik dan benar. Hal ini dilakukan agar siswa memiliki kesiapan mental untuk melaksanakan membaca dengan buku, (3) diharapkan lebih maksimal memberikan motivasi kepada siswa untuk membaca melalui media pembelajaran yang menarik sehingga minat membaca siswa meningkat, dan (4) dalam melaksanakan pembelajaran bahasa
Indonesia sebaiknya menekankan pada proses daripada hasil.

Secara umum pembelajaran membaca dengan strategi Multiple Games dapat dikembangkan di kelas lain dalam pembelajaran membaca atau dikembangkan di gugus sekolah dalam kegiatan kelompok kerja guru (KKG). Pembelajaran dengan strategi Multiple Games diharapkan juga dapat memberikan sumbangan bagi peneliti lanjutan untuk memperkaya pengetahuan, wawasan, dan referensi tentang penggunaan strategi Multiple Games dalam pembelajara membaca permulaan.

\section{DAFTAR RUJUKAN}

Akhadiah, Sabarti. 1992/1993. Bahasa Indonesia I. Jakarta:Depdikbud Dirjen Dikti P2TK.

Burn: Paul C: Roe. Betty D; Ross, Elinor P. 1996. Teaching Reading in Today's Elementary School. Boston: Houghton Mifflin.

Depdiknas. 2003. Model Pembelajaran Bahasa Indonesia Sekolah Dasar. Jakarta: Dirjen Pendidikan Dasar dan Menengah.

Karwapi. 1974. Pengantar Bahasa Indonesia di SD: Petunjuk Mengajar Membaca Menulis Permulaan Tanpa Buku. Bandung: Angkasa.

Misdar. 2006. Peningkatan Kemampuan Membaca Pemahaman dengan Strategi Tanya Jawab. Tesis. Tidak Diterbitkan. Malang. PPs IKIP Malang.

Mistiana. 2005. Strategi Pembelajaran Membaca Permulaan Kelas I SD Negeri Sekecamatan Kedungkanda$n g$. Skripsi. Tidak Diterbitkan. Malang: FKIP Universitas Negeri Malang.

Nisrinah, Siti. 2000. Pembelajaran Membaca Permulaan Melalui Permainan Bahasa. Tesis. Tidak Diterbitkan. Malang: PPS UM. 
Riyanto. 2005. Paradigma Pembelajaran. Surabaya :UNESA PRESS.

Roestiyah. 1990. Strategi Belajar Mengajar. Jakarta: Rineka Cipta.

Rusyan. 1992. Pendekatan dalam Proses Belajar Mengajar. Bandung: Remaja Rosdakarya.

Sadiman. 1986. Interaksi dan Motivasi BeBelajar Mengajar Pedoman Bagi Guru. Jakarta: Rajawali.

Suyono dan Muslich, Mansyur. 1996. Panduan Pengajaran Bahasa Indonesia. Malang: YA3.Malang.

Syafi'ie, Imam. 1999. Pengajaran Membaca di Kelas-kelas Awal Sekolah Dasar: Pidato Pengukuhan Guru Besar dalam Bidang Ilmu Penga- jaran Bahasa Indonesia. Malang: FPBS UM.

Tampubolon. 1999. Mengembangkan Minat dan Kemampuan Membaca. Jakarta: Rajawali.

Zubaidah, Eny. 1998. Diagnosis dan Tindakan Perbaikan Kesalahan Membaca Kelas I SDN Penanggungan III Malang. Tesis Tidak Diterbitkan Malang: PPS IKIP Malang.

Zuchdi, Darmiati dan Budiarsih. 1996/1997. Pendidikan Bahasa dan Sastra Indonesia di Kelas Rendah. DepDikbud. Dirjen DikTi P2PGSD IBRD: Loan 3496. INN.

Zuriah, Nurul. 2002. Penelitian Pendidikan dan Penulisan Karya Ilmiah, Malang: UMM Press. 